Synonymy of Ejectosporus magnus and Simuliomyces spica, and a New Species, Ejectosporus trisporus, from Winter-Emerging Stoneflies

Author(s): D. B. Strongman

Source: Mycologia, Vol. 97, No. 2 (Mar. - Apr., 2005), pp. 552-561

Published by: Mycological Society of America

Stable URL: http://www.jstor.org/stable/3762272

Accessed: 17-06-2015 12:16 UTC

Your use of the JSTOR archive indicates your acceptance of the Terms \& Conditions of Use, available at http://www.jstor.org/page/ info/about/policies/terms.jsp

JSTOR is a not-for-profit service that helps scholars, researchers, and students discover, use, and build upon a wide range of content in a trusted digital archive. We use information technology and tools to increase productivity and facilitate new forms of scholarship. For more information about JSTOR, please contact support@jstor.org. 


\section{Synonymy of Ejectosporus magnus and Simuliomyces spica, and a new species, Ejectosporus trisporus, from winter-emerging stoneflies}

\author{
D.B. Strongman ${ }^{1}$ \\ Department of Biology, Saint Mary's University, \\ Halifax, Nova Scotia, B3H 3C3 Canada
}

\begin{abstract}
The Trichomycete, Ejectosporus magnus, from Allocapnia spp. was determined to be a vegetative spore stage of another harpellid, Simuliomyces spica. A voucher slide of E. magnus made from a stonefly nymph that was part of the same collection as the holotype had thalli bearing trichospores of both E. magnus and S. spica. I conclude that these are one species; therefore Ejectosporus is emended and the species is treated as E. spica. Also, a new species, E. trisporus, is described from Allocapnia pygmaea (Plecoptera: Capniidae) collected in eastern Canada. This species has vegetative spores and trichospores with characteristics similar to $E$. spica, but the two species are separated by differences in zygospore sizes.
\end{abstract}

Key words: gut fungi, Harpellales, symbiotic, taxonomy, trimorphic

\section{INTRODUCTION}

The Trichomycetes are a group of fungi associated with the digestive tracts of insects and other invertebrates. Studies of these fungi have typically also included other groups of gut-inhabiting organisms, such as Paramoebidium spp. (Amoebidiales), that produce amoeboid cells and now are considered protists (Lichtwardt et al 2001a). Molecular analyses suggest that the fungal orders within the Trichomycetes are not a natural group and that members of the Harpellales are most closely related to the Kickxellales (Zygomycetes) (Benny and White 2001, Gottlieb and Lichtwardt 2001, White 2002).

The Harpellales are probably the best-known group of Trichomycetes, and this order contains the largest number of described species (Lichwardt 1986, Lichtwardt et al 2001a). The genera and species are separated primarily on the morphology of the asexual trichospores and sexual zygospores. Consideration is also given to features of the thallus such as

Accepted for publication 4 Nov 2004.

${ }^{1}$ E-mail: doug.strongman@smu.ca branching patterns, septation and holdfast characteristics. A few species exhibit dimorphism manifested as either different trichospore sizes or the production of vegetative propagules in addition to trichospores and zygospores (Lichtwardt et al 2001a). In addition there appears to be some degree of host specificity, at least to host order (Lichtwardt 1986).

Winter-emerging stoneflies in the family Capniidae have been a rich source of Trichomycete species wherever these hosts have been examined. Peterson and Lichtwardt (1983) and Lichtwardt et al (1991) have reported four species from the hindguts of stoneflies of the genus Allocapnia Claassen, often cooccurring in a single nymph. Species described from Allocapnia include Simuliomyces spica S.W. Peterson \& Lichtw. and Genistelloides hibernus S.W. Peterson, Lichtw. \& B.W. Horn, and these both produce typical harpellid trichospores and zygospores (Lichtwardt 1986). Simuliomyces spica was separated from the type species Simuliomyces microsporus Lichtw. based on differences in trichospore dimensions, thallus features and the fact that $S$. microsporus occurs in blackfly (Simuliidae) larvae. Both species share Type I zygospores, and the morphological features of the sexual spores overlap considerably (Peterson and Lichtwardt 1983).

Ejectosporus magnus S.W. Peterson, Lichtw. \& M.C. Williams also was described from Allocapnia spp. stoneflies, and this monotypic genus was defined mostly by an unusual feature of the trichospore (Lichtwardt et al 1991). The trichospore is not released from the thallus (nondeciduous); rather a lunate sporangiospore is extruded from the monosporous sporangium in the gut where it was produced. Lichtwardt et al (1991) in their original description questioned the adaptive value of this mechanism for transmission from host to host. They also noted the co-occurrence of $E$. magnus with other species in the host gut and made specific reference to the frequent association of $S$. spica, and other harpellid species, with $E$. magnus. I present data in this paper to warrant emending the description of Ejectosporus and synonymizing E. magnus and S. spica.

Records of Trichomycetes in Canada are sparse with only two published accounts from Newfoundland (Frost and Manier 1971, Lichtwardt et al 2001b) and some references to Canadian collections in 
Lichtwardt et al (2001a). Collections of these fungi in Prince Edward Island (PEI) and Nova Scotia (NS) will be reported elsewhere, but over the course of these studies I collected stoneflies (Allocapnia pygmaea Burmeister) that routinely contained a complex of up to four species of gut fungi and two species of Paramoebidium L. Leger \& Duboscq in a single host. A new species, E. trisporus is described from Tyne Valley, PEI, that belongs in the emended genus Ejectosporus.

\section{MATERIALS AND METHODS}

Stoneflies identified as Allocapnia pygmaea (Harper and Hynes 1971, Stewart and Stark 1988) were collected in a D-net by kick sampling at two sites in PEI, Arlington $\left(46^{\circ} 31^{\prime} 21^{\prime \prime} \mathrm{N}\right.$, $\left.63^{\circ} 55^{\prime} 09^{\prime \prime} \mathrm{W}\right)$ and Tyne Valley $\left(46^{\circ} 34^{\prime} 14^{\prime \prime} \mathrm{N}, 63^{\circ} 55^{\prime} 44^{\prime \prime} \mathrm{W}\right)$, and at Sackville, NS $\left(44^{\circ} 46^{\prime} 15^{\prime \prime} \mathrm{N}, 63^{\circ} 41^{\prime} 22^{\prime \prime} \mathrm{W}\right)$. Samples were taken at the PEI sites 14 Dec 2002, 17 Dec 2003 and 16 Feb 2004 and at the NS site 3 Nov and 21 Dec 2003 and 1, 5, 13 Jan and 3 Mar 2004. These collections spanned the mid to late stages of nymph development. The hindguts were removed from the nymphs with fine forceps and dissected in distilled water. Wet mounts were examined for Trichomycete thalli and spores. The fungi were identified using keys in Lichtwardt (1986) and Lichtwardt et al (2001a). Morphological data on fungal structures and digital images were recorded on a Zeiss Axioplan digital microscopy system at the Saint Mary's University Taxonomy Laboratory, and semipermanent slides were made of fungi stained with lactophenol cotton blue according to instructions in Lichtwardt (1986). Reference collections of the insect hosts were preserved in $80 \%$ ethanol.

\section{RESULTS}

Synonymy of Simuliomyces spica and Ejectosporus magnus.-Lichtwardt et al (1991) in their original description of E. magnus commented on the co-occurrence of this species with other Trichomycetes, specifically $S$. spica, in the gut of Allocapnia stoneflies. My observations of single thalli producing trichospores characteristic of both these species in $\mathrm{Al}$ locapnia pygmaea from eastern Canada prompted me to examine the holotypes and other collections of $E$. magnus and $S$. spica to determine the true identity of these fungi.

Lichtwardt's slide (AL-7-21) prepared from nymphs that were part of the holotype collection of $E$. magnus contained a thallus bearing trichospores of both E. magnus and S. spica on separate branches (FIGs. 1-4). This provides evidence that the two fungi are actually one species so should be synonymized. For reasons explained fully below this species is best placed in Ejectosporus after emendment of the genus concept.
Ejectosporus S.W. Peterson, Lichtw. \& M.C. Williams emend. Strongman

Three spore types produced. Trichospores bearing 2 appendages, typically $8-16$ spores produced at the distal ends of thin, fertile branches. Vegetative spores produced on thicker branches (4-6/branch), extruding lunate sporangiospores in situ with the sporangial and spore wall remaining attached to the branch. $\mathrm{Zy}$ gospores biconical, tips colinear or slightly bent toward zygosporophore when mature, zygosporophores slightly swollen at the point of attachment to the spore, medially, at right angles to the zygospore (Type I).

Ejectosporus magnus and S. spica could be placed in either Ejectosporus or Simuliomyces. The type species, S. microsporus, was described from blackfly larvae (Lichtwardt 1972). Also, the number of trichospore appendages is variable (2-4), and they are long and thin. The thallus of $S$. microsporus is regularly septate, branched from a basal holdfast and produces trichospores along the entire length of the branches. The generative cells are typically longer than the trichospores. Zygospores are borne on short, bulbous zygosporophores.

Simuliomyces spica, from stonefly nymphs, is distinguished from $S$. microsporus by trichospore size, appendage number and differences in the zygosporophore (Peterson and Lichtwardt 1983). The thallus of S. spica is mostly non-septate, it has long branches arising from a prostrate central axis and the trichospores are produced in series along the fertile tips of these branches with the trichospores normally longer than the generative cells. The zygosporophore is long and only slightly enlarged where it joins onto the zygospore. Peterson and Lichtwardt (1983) noted that both the stonefly host and blackfly larvae cohabited the type locality for $S$. spica, but neither $S$. spica nor $S$. microsporus was found colonizing the blackfly host at that site, implying that $S$. spica, although present, was not capable of colonizing the typical host (blackfly) for $S$. microsporus.

Examination of the type slides of $S$. microsporus (WYO-14-19), E. magnus (AL-7-15) and other slides of both E. magnus and S. spica obtained from the collection of Dr. R.W. Lichtwardt confirmed the morphological differences between $S$. spica and $S$. microsporus described above. The type slide of $S$. spica (MIS-9-102) unfortunately had deteriorated, but the zygospore characteristics were still visible. Simuliomyces microsporus has never been reported, as yet, to produce vegetative spores, although it has been widely collected (Lichtwardt 1972, Lichtwardt et al 2001a). Therefore the differences between S. spica and the type species, as well as the recognition of a 


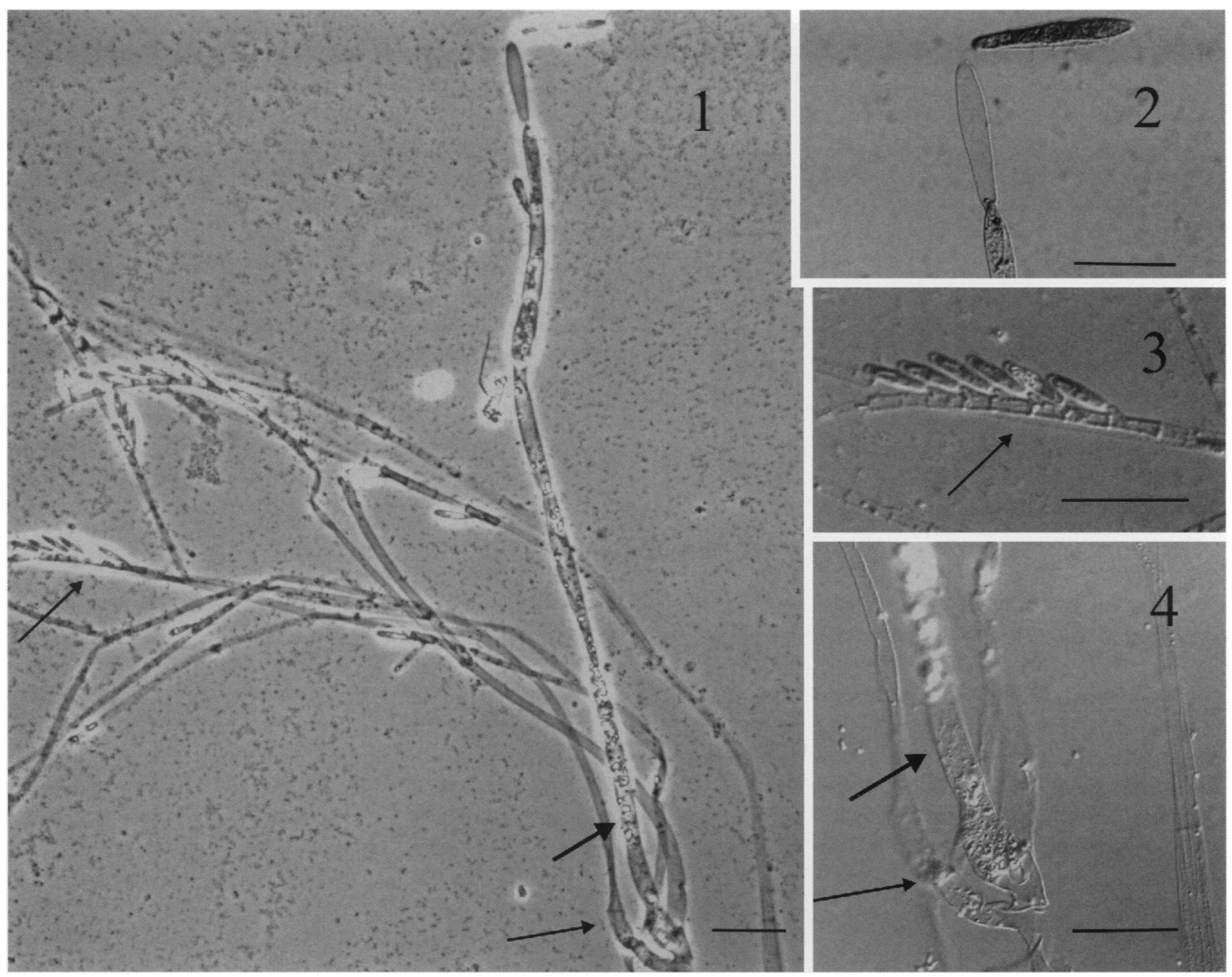

FIGS. 1-4. Ejectosporus magnus (Slide AL-7-21) from R.W. Lichtwardt, University of Kansas. 1. Thallus showing branches bearing either spores of Ejectosporus magnus (big arrow) or trichospores of Simuliomyces spica (small arrows) arising from a common basal cell. 2. Vegetative spore released from sporangium. 3. Trichospore details at small arrow in Fig. 1. 4. Details of the branching from the basal cell. Large arrow is base of branch bearing vegetative spore, branch at small arrow has trichospores. Scale bars: $1=50 \mu \mathrm{m}, 2-4=20 \mu \mathrm{m}$.

vegetative spore stage in the life history of $S$. spica, support moving $S$. spica out of the genus.

Ejectosporus magnus is monotypic and is recognized here as a vegetative spore form of $S$. spica. The evidence supports moving $S$. spica out of the genus Simuliomyces so Ejectosporus is emended above to accommodate $S$. spica. Because the epithet spica is older than magnus it is used for the new combination.

Ejectosporus spica (S.W. Peterson \& Lichtw.) Strongman comb. nov.

$==$ Simuliomyces spica S.W. Peterson \& Lichtw. Mycologia 75:246. 1983.

$==$ Ejectosporus magnus S.W. Peterson, Lichtw. \& M.C. Williams Mycologia 83:389. 1991.

Thallus branched, from a prostrate central axis, branches forming either elongate-ellipsoidal trichospores 12-14(-16) $\times 2 \mu \mathrm{m}$, no collar, with 2 short, stiff appendages, or, nondeciduous, vegetative spores, clavate to elongate-ellipsoidal 50-85 $\times 8-10 \mu \mathrm{m}$. Vegetative spores extruding lunate sporangiospores in situ. Zygospores biconical, 36-43 $\times 7-10 \mu \mathrm{m}$, attached to zygosporophores medially, at right angles (Type I), zygosporophore slightly swollen, formed from swellings along one of the pair of hyphae undergoing scalariform conjugations, resulting often in a row of zygospores produced. Attached to hindgut of Allocapnia sp. (Plecoptera: Capniidae) nymphs.

Specimens examined. USA. ALABAMA: microscope slides of $E$. magnus AL-7-15 (HOLOTYPE FH), AL-7-6 (ISOTYPE), AL-7-1, AL-7-8, and AL-7-21. TEXAS: microscope slides of $E$. magnus, TX-1-1, TX-1-2, TX-1-10. OKLAHOMA: 
microscope slide OK-2-3 of $E$. magnus. Collection details can be found in Lichtwardt et al (1991). MISSOURI: microscope slide (MIS-9-102) of S. spica (HOLOTYPE FH). All slides, other than the holotypes, were borrowed from the collection of R.W. Lichtwardt, University of Kansas. All the slides had thalli identified as E. magnus and S. spica on them.

New species of Ejectosporus from eastern Canada.-Trichomycete species recovered from Allocapnia pygmaea collected at two sites in eastern Canada included Genistelloides hibernus, Capniomyces stellatus S.W. Peterson \& Lichtw., a species with characteristics similar to E. spica, an unidentified species of Lancisporomyces Santam., and the protistans, Paramoebidium corpulentum Lichtw. \& M.C. Williams and a Paramoebidium sp. All these organisms frequently were found together in the hindgut of a single host.

Individual thalli bearing two types of spores like $E$. spica were observed in this host (FIGS. 5 and 6). I also observed that some spores were extruded and attached themselves to the hindgut or thalli within the host where they were produced (FIGS. 7 and 8) then proceeded to grow there (FIG. 9), suggesting that this trichospore type is vegetative in function rather than dispersive like other harpellid trichospores. These extruded vegetative spores appear to branch at the base and can produce trichospores from a reduced thallus composed of only a few branches (FIGS. 10 and 11). Zygospores and trichospores were seen in the guts of A. pygmaea in the final nymph stages collected at the PEI and NS sites. Zygospore size fell wholly outside the range for the closest matching species, $S$. spica (=E. spica). This fungus then, with three functionally different spore types, matches the emended description of Ejectosporus but is separated from the type species on the basis of zygospore size so is described here as a new species.

\section{Ejectosporus trisporus Strongman sp. nov. FIGS.}

$12-16$

Thallus ab axe centrale prostratoque ramosus; rami aut trichosporas elongato-ellipsoideas $12-18.5 \times 4.5 \mu \mathrm{m}$, sine collo, appendicibus 2 brevibus rigidisque, aut sporas vegetativas nondeciduasque clavatas vel elongate-ellipsoideas 72-86 $\times$ 8-11.5 $\mu \mathrm{m}$ formantes. Zygosporae biconicae, 54 $71 \times 9-12.5(-14) \mu \mathrm{m}$, ad zygosporophora ad angulum $90^{\circ}$ medifixae (Typus I); zygosporophorum leviter tumidum, a tumoribus secus hypham unicam paris conjugations scalarformes subientis, ut series zygosporarum saepe gignitur. In proctodaeo nympharum Allocapniarum affixus.

Thallus branched, sometimes from a prostrate central axis, branches form either trichospores 12-18.5 $\times 2-4.5 \mu \mathrm{m}$ with 2 short, stiff appendages and no collar, or nondeciduous, vegetative spores, elongateellipsoidal $72-86 \times 8-11.5 \mu \mathrm{m}$ when fully mature
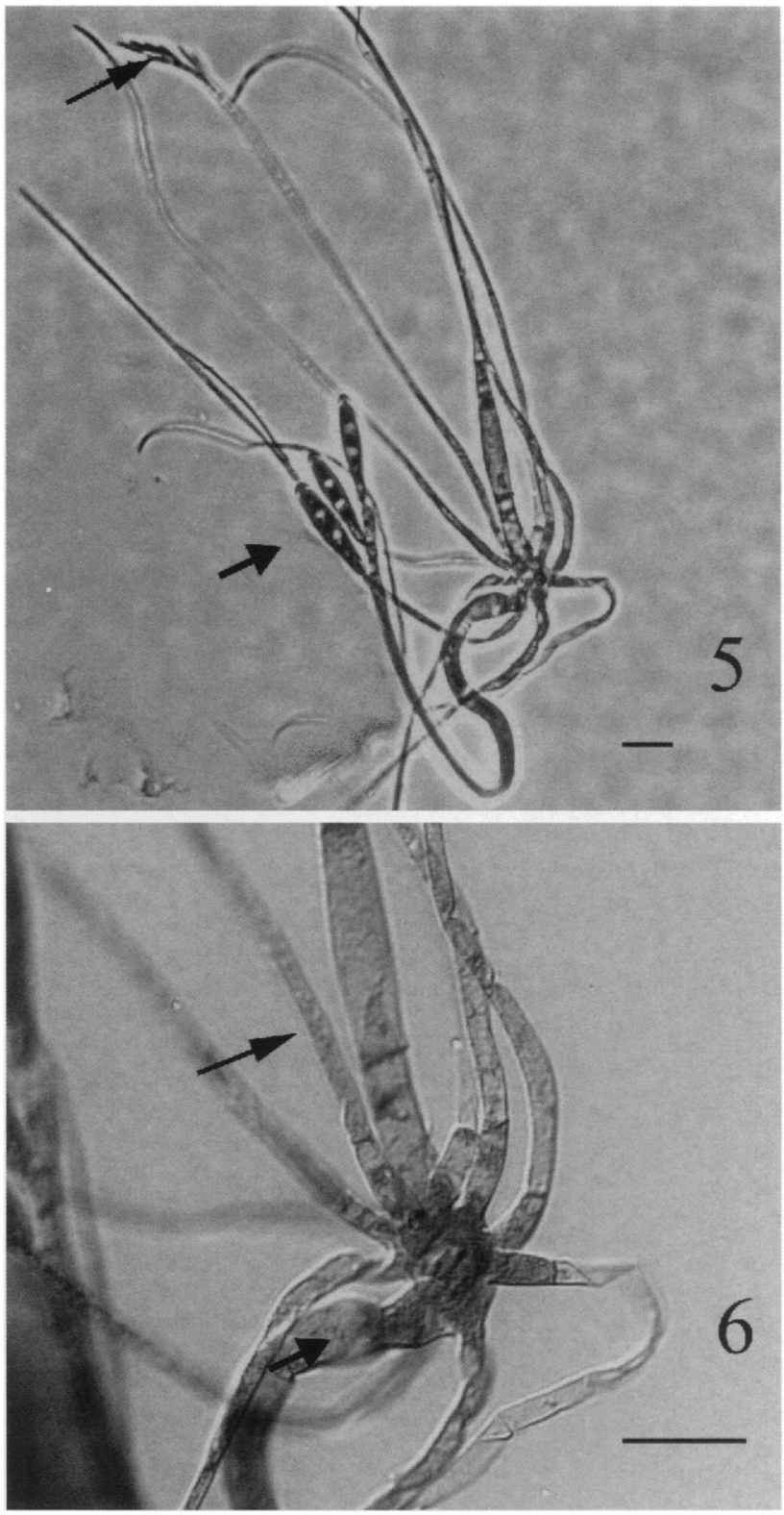

Figs. 5 and 6. Thallus of Trichomycete from Allocapnia stoneflies collected from eastern Canada. 5. Single thallus bearing vegetative spores (big arrow) and trichospores (small arrow) like E. spica. 6. Details of branching at base of thallus. Branch at large arrow bearing vegetative spores, small arrow indicates a branch with trichospores. Scale bars: 5 and $6=20 \mu \mathrm{m}$.

(FIG. 12). Branches forming trichospores thin (3-5 $\mu \mathrm{m}$ wide at base) with 8-16 trichospores forming along one side of the fertile tip (FIGS. 13 and 14). Vegetative spores formed on thicker (5-8 $\mu \mathrm{m})$ branches extruding lunate sporangiospores in situ leaving the sporangial and spore walls attached to the thallus (FIG. 7). Zygospores biconical, 54-71 $\times 9$ 12.5(-14) $\mu \mathrm{m}$ attached to the zygosporophore medially at right angles (Type I) with tips slightly bent 

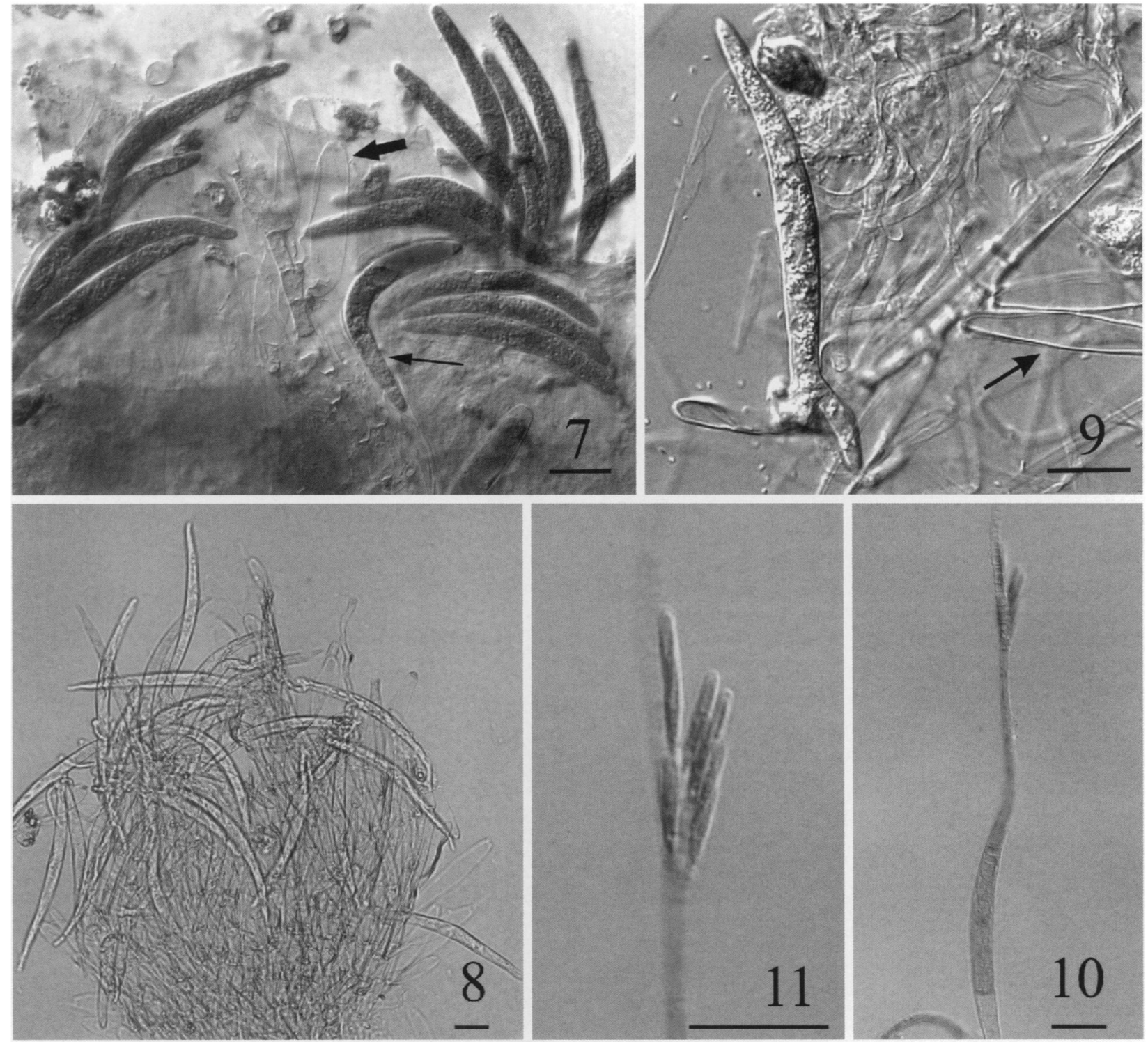

FIGs. 7-11. Vegetative spores. 7. Vegetative spores released and attached to hindgut of the host. Big arrow indicates spore wall attached to the thallus, small arrow shows spore extruding. 8. Extruded spores attached to spent thalli. 9. Extruded vegetative spore beginning to branch while attached to a thallus. Spent sporangia at arrow. 10. Thallus from extruded vegetative spore producing trichospores. 11. Trichospores. Scale bars: 7-11 $=20 \mu \mathrm{m}$.

toward the zygosporophore, zygosporophore slightly swollen, 24-32.5 $\times 5-6.5(-8.5) \mu \mathrm{m}$ (Figs. 15 and 16), formed from swellings along one of the pair of hyphae undergoing scalariform conjugations, resulting often in a row of zygospores produced. Rarely, zygospores are released without the zygosporophore attached. Attached to the hindgut of Allocapnia (Plecoptera: Capniidae) nymphs.

Specimens examined. CANADA. PRINCE EDWARD ISLAND: Tyne Valley, $46^{\circ} 34^{\prime} 14^{\prime \prime} \mathrm{N}, 63^{\circ} 55^{\prime} 44^{\prime \prime} \mathrm{W}$. Microscope slide TV-1 prepared from a specimen of A. pygmaea collected on 16 Feb 2004 (HOLOTYPE FH). This slide illustrates the trichospores and zygospores only. Slides TV-5, 14 Dec 2002 and TV-4, 14 Dec 2002 (PARATYPES FH) from the type locality show vegetative spores and trichospores. The type and paratype slides also contain sporulating thalli of G. hibernus and some species of the protistan, Paramoebidium. Arlington, $46^{\circ} 31^{\prime} 21^{\prime \prime} \mathrm{N}, 63^{\circ} 55^{\prime} 09^{\prime \prime} \mathrm{W}$. Slides prepared from A. pygmaea on 17 Dec 2003 and 16 Feb 2004. NOVA SCOTIA: Sackville, $44^{\circ} 46^{\prime} 15^{\prime \prime} \mathrm{N}, 63^{\circ} 41^{\prime} 22^{\prime \prime} \mathrm{W}$. Slides prepared from A. pygmaea on 3 Nov and 21 Dec 2003, 1, 5, 13 Jan and $3 \mathrm{Mar}$ 2004. Zygospores and trichospores (no vegetative spores) were observed on the slides from the Jan and Mar collections. All slides other than the holotype and paratype are in the author's collection.

Commentary. Ejectosporus trisporus and E. spica overlap in morphology and in the size ranges of trichospores and vegetative spores. The zygospores have 

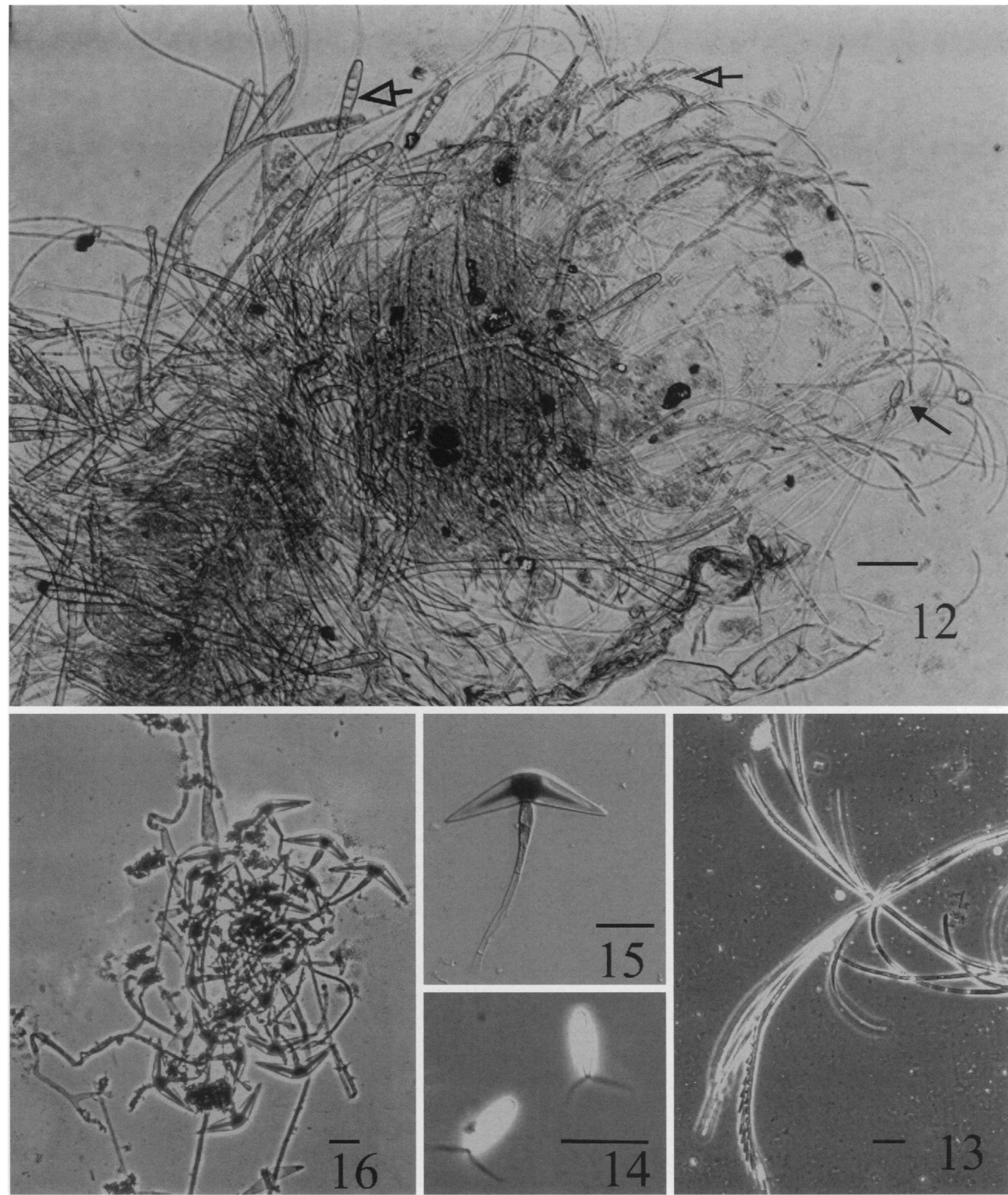

Figs. 12-16. Ejectosporus trisporus. 12. Thalli of $E$. trisporus with both vegetative spores (large open arrow) and trichospores (small open arrow). Note trichospore of Genistelloides hibernus at filled arrow, lower right. 13. Trichospores in row along one side of fertile tip. 14. Released trichospores with two short, stiff appendages. 15. Released zygospore. 16. Mass of zygospores. Scale bars: $12=50 \mu \mathrm{m}, 13-16=20 \mu \mathrm{m}$. 


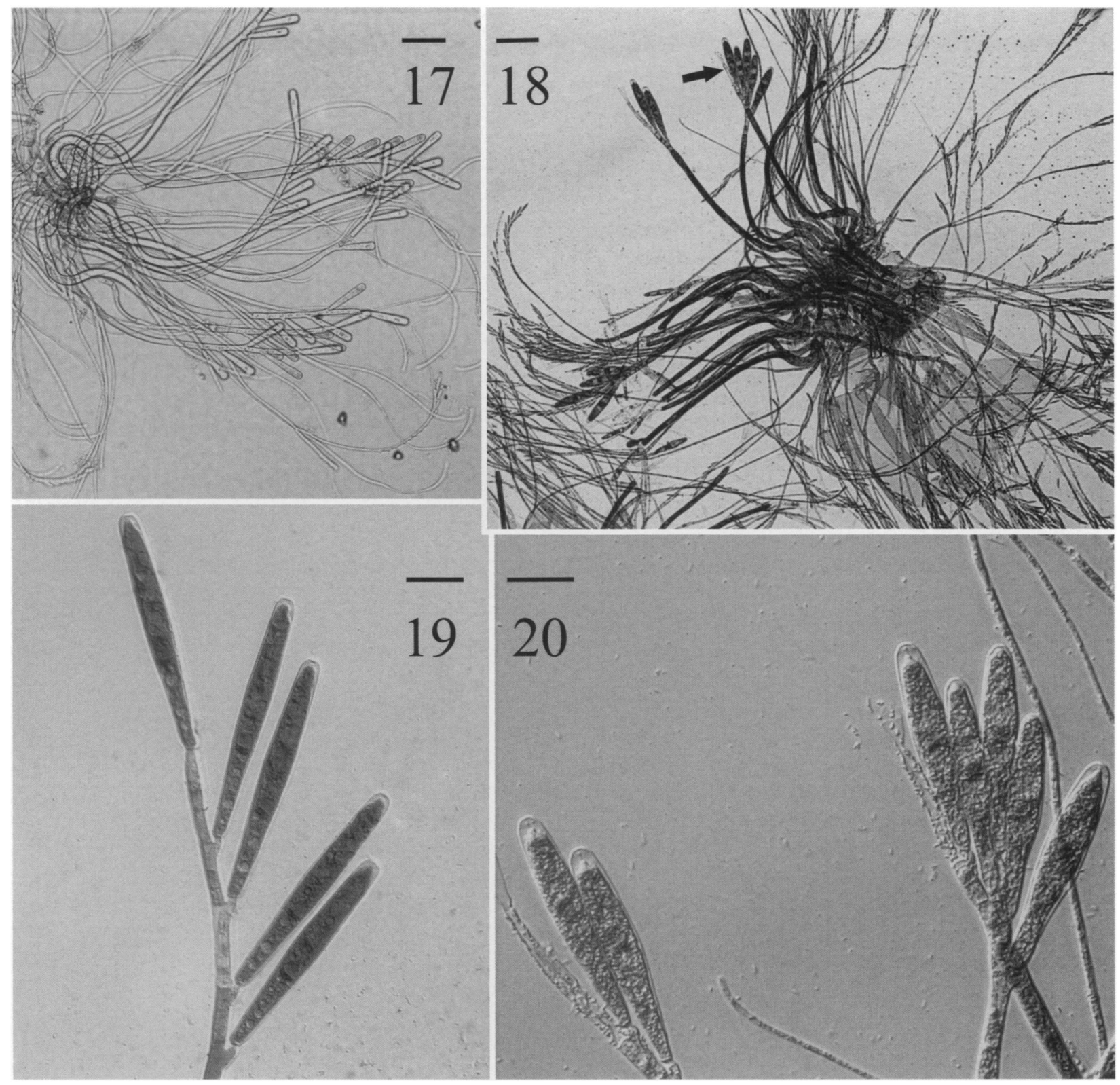

FiGs. 17-20. Morphology of vegetative spores of E. trisporus and E. spica. 17. Branches producing immature vegetative spores of $E$. trisporus. Note sigmoid base on branches. 18. Branches producing nearly mature vegetative spores (arrow) of E. spica. 19. Elongate-ellipsoidal mature spores of E. trisporus. 20. Clavate, mature spores of E. spica. Scale bars: 17 and 18 $=50 \mu \mathrm{m}, 19$ and $20=20 \mu \mathrm{m}$.

similar developmental features but the longer length and width of the spore in $E$. trisporus easily separates the two species. Both species produce trichospores that are similar in shape, appendage characteristics and ontogeny. Spore dimensions vary, but a frequency analysis on spore length of $E$. trisporus from PEI and NS showed most $(73 / 100)$ were 14-16 $\mu \mathrm{m}$ (range 12-19 $\mu \mathrm{m}$ ) long whereas those of E. spica are slightly shorter at $12-15 \mu \mathrm{m}(101 / 120$, range $10-17)$, based on measurements made from the slides borrowed from R.W. Lichtwardt. The vegetative spores in both species are borne on nonseptate, thick branches, which often are sigmoid at the base (FIGS. 17 and 18). When fully mature, the spores are distinctly elongate-ellipsoidal in E. trisporus (FIG. 19), whereas they are more clavate in E. spica (FIG. 20). The overlap in trichospore and vegetative spore dimensions between the two species of Ejectosporus may pose a difficulty in separating them with confidence if zygospores are not present.

Frequently larger $(22-32 \times 4-6.5 \mu \mathrm{m})$ trichospores with two appendages (FIGs. 21 and 22) oc- 

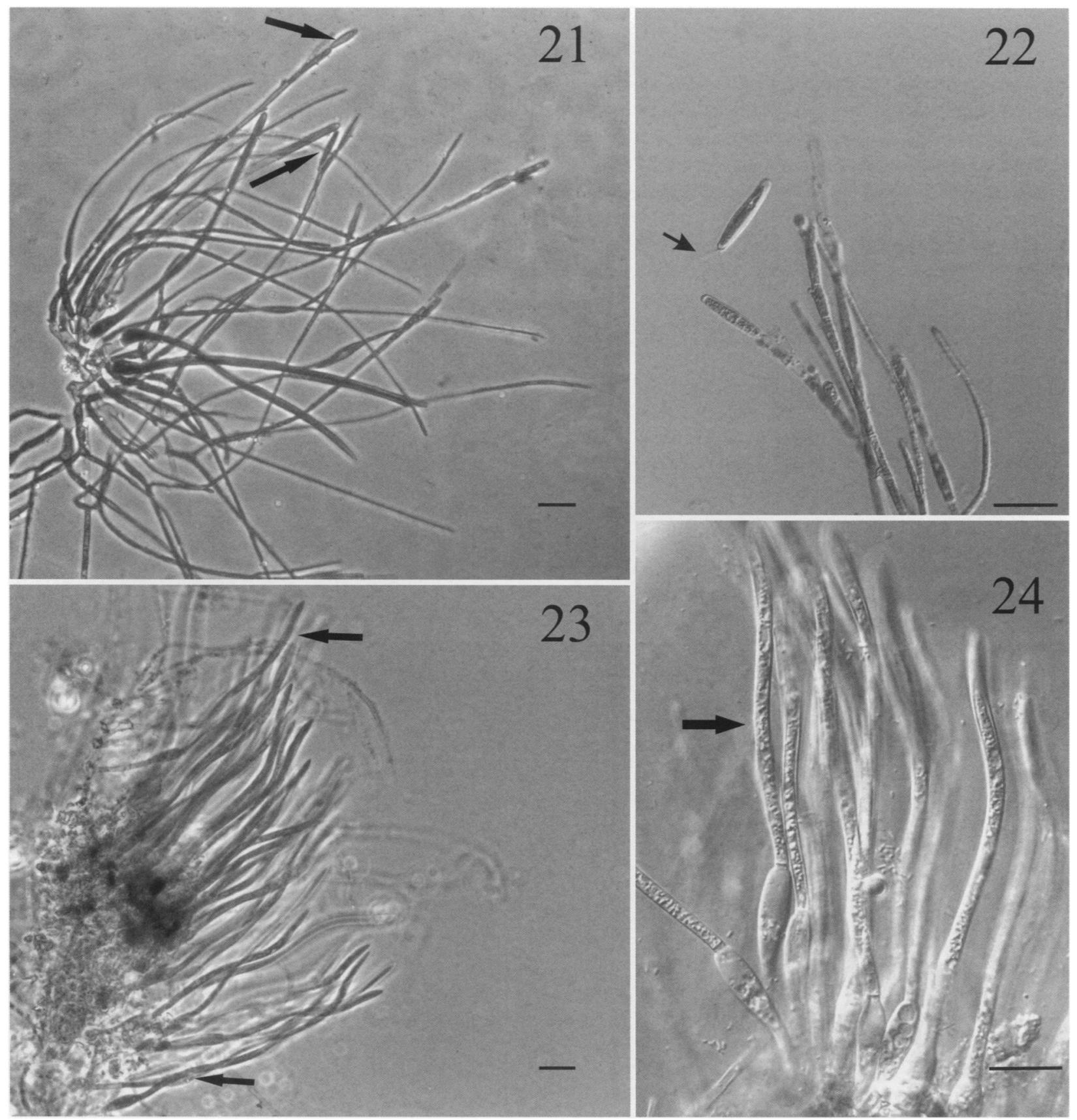

FIGS. 21-24. Large trichospores in Allocapnia pygmaea. 21. Thallus bearing large trichospores (arrows). 22. Released trichospore with two appendages (arrow). 23. Thallus with zygospores of a Lancisporomyces sp. (arrows). 24. Details of Lancisporomyces sp. zygospore, elongated part of the spore at the arrow and bulbous base below. Scale bars: 21-24 $=20 \mu \mathrm{m}$.

curred on thalli in guts of stoneflies collected at the PEI and NS sites. These trichospores are borne on thalli with characteristics similar to $E$. trisporus (FIG. 21), but the size, shape and appendage characteristics (FIG. 22) are similar to trichospores of Lancisporomyces or Genistelloides S.W. Peterson, Lichtw. \& B.W. Horn. An unidentified species of Lancisporomyces also occurred in the Allocapnia hosts that contained $E$. trisporus (FIGS. 23 and 24); however, I could not di- rectly connect these large trichospores with the zygospores of the unidentified Lancisporomyces so no definitive identification based on these trichospores is possible.

\section{DISCUSSION}

Ejectosporus spica and E. trisporus both produce a unique trichospore that is vegetative in function, an- 
other form of trichospore that is dispersive, and a sexual zygospore. Spore types whose function appear to be recolonization of the infested host are known in two other genera of Trichomycetes, the monotypic Allantomyces caenidarum M.C. Williams \& Lichtw. and Graminella L. Leger \& M.Gauthier ex Manier, with two species. Both Graminella species produce vegetative propagules that form in clusters at the base of the thallus and develop into new thalli within the gut of the host where they were produced (Lichtwardt and Moss 1981). The ontogeny and release mechanism of these are completely different from the vegetative spores of E. spica and E. trisporus. Allantomyces caenidarum produces allantoid vegetative spores on the same branches with trichospores (Williams and Lichtwardt 1993). These vegetative cells detach and can extrude and grow into thalli in the gut of the same host. Ephemerellomyces aquilonius M.M. White \& Lichtw. also produces trichospores that detach and can extrude in situ (White and Lichtwardt 2004). In this species no morphologically distinct vegetative spore exists; however, some trichospores appear to extrude and produce a small thallus that sporulates immediately. The vegetative spores in these species differ morphologically and detach from the thallus before they extrude which differentiates them from the vegetative spores produced in E. spica and E. trisporus.

Another harpellid, Legeriomyces aenigmaticus Lichtw. \& M.C. Williams, produces trichospores with three different size ranges. The spores are released into the environment and, to my knowledge, none have a vegetative function like Graminella, Allantomyces, Ephemerellomyces or Ejectosporus.

Within the Harpellales only one genus has members that are known from more than one order of host. Glotzia plecopterorum Lichtw. inhabits stoneflies (Plecoptera), while the other five species occur in mayflies (Ephemeroptera) (Misra and Lichtwardt 2000, White and Lichtwardt 2004). This suggests that harpellids typically show some degree of host specificity so the transfer of S. spica out of Simuliomyces is supported because the type species, $S$. microsporus occurs in a different order (Diptera).

Peterson and Lichtwardt (1983) in placing S. spica in that genus rather than Genistelloides noted that, among other characteristics, the zygospores of $S$. spi$c a$ were more flattened where the zygosporophore was attached whereas those of Genistelloides spp. had tips of the zygospore bent toward the zygosporophore. The zygospores of $E$. trisporus are typically bent (FIG. 16) as in Genistelloides spp., but the trichospore features and presence of vegetative spores in E. trisporus clearly differentiate this species from species of Genistelloides.
In the original species description of $E$. magnus Lichtwardt et al (1991) described long, thin branches that appeared to be sterile. These sterile branches commonly were observed on thalli also producing branches bearing vegetative spores of E. trisporus from collections in eastern Canada. Some thalli do produce trichospores on these long, thin branches and vegetative spores simultaneously, on separate branches arising from the central axis of the thallus. Of note, these long, sterile branches also are found on thalli producing zygospores, but trichospore production is rarer on these thalli than on those producing both trichospores and vegetative spores.

Lichtwardt et al (1991) questioned the adaptive value of the rapid, within-host release of the trichospore contents for spore dispersal and transmission in E. magnus. It seems that this spore stage functions to increase thallus density within the gut of a host and therefore works in conjunction with the dispersive trichospore stage to increase the spore load in the environment and promote colonization within the host population. The prevalence of vegetative spore production in the earlier stages of host development, as seen in E. trisporus, supports this idea. As the host develops into the pre-adult stages the disappearance of the vegetative stage coincides with zygospore production. This adaptation to the reduced number of available hosts along with their low vagility might indicate a strategy where the fungus retreats to the sediments or vegetation until the next generation of stoneflies is active, which can be several months later. An interesting question to explore is whether young nymphs are infested before diapause or if the fungus exists in a dormant phase (e.g., zygospores) in the environment until the host becomes available again.

\section{KEY TO SPECIES OF SIMULIOMYCES AND EJECTOSPORUS}

1a. Thallus regularly septate, branches short, with longellipsoidal trichospores $(20-26 \times 4-5 \mu \mathrm{m})$ produced from small outgrowths along the whole branch, biconical zygospores (34-45 $\times 7-8 \mu \mathrm{m})$ borne on short bulbous zygosporophores, in blackfly larvae (Simuliidae) ... . Simuliomyces microsporus

1b. Long branches arising regularly either from a prostrate central axis or from the base of an enlarged cell, non-septate except near base of branches and where spores form, trichospores $(<20 \mu \mathrm{m})$ produced along one side at fertile tip of long branches, may have nondeciduous vegetative spores produced on thicker branches or biconical zygospores attached at right angles to the zygosporophore, in stonefly nymphs (Capniidae) $\ldots \ldots \ldots \ldots \ldots .2$

2a. Vegetative spores slightly clavate $(50-85 \times 8-10$ $\mu \mathrm{m}), 4-6$ spores produced terminally and along the fertile tip of thick branches, lunate sporangiospore 
ejected from sporangium when mature, zygospores $36-43 \times 7-10 \mu \mathrm{m} \ldots \ldots \ldots \ldots$ Ejectosporus spica

2b. Vegetative spores elongate-ellipsoidal $(72-86 \times 8-$ $11.5 \mu \mathrm{m}), 4-6$ spores produced terminally and along the fertile tip of thick branches, lunate sporangiospore ejected from sporangium when mature, zygospores $54-71 \times 9-12.5(-14) \mu \mathrm{m} \ldots$ E. trisporus

\section{ACKNOWLEDGMENTS}

The author thanks Dr R.W. Lichtwardt and Dr M.M. White, University of Kansas, for advice and encouragement as well as the loan of slides and for reviewing early versions of the manuscript and Dr D. Pfister, Farlow Herbarium, Harvard University, for assistance with the nomenclatural aspects in this paper. Thanks also to Carolyn Bird for preparing the Latin diagnosis. Type specimens for study were kindly provided by the Farlow Herbarium (FH). The Faculty of Graduate Studies and Research, Saint Mary's University, provided financial support.

\section{LITERATURE CITED}

Benny GL, White MM. 2001. The classification and phylogeny of Trichomycetes and Zygomycetes. In: Misra JK, Horn BW, eds. Trichomycetes and other fungal groups. Enfield, New Hampshire: Science Publishers Inc. p 3953.

Frost S, Manier J-F. 1971. Notes on Trichomycetes (Harpellales: Harpellaceae and Genistellaceae) in larval blackflies (Diptera: Simuliidae) from Newfoundland. Can J Zool 49:776-778.

Gottlieb AM, Lichtwardt RW. 2001. Molecular variation within and among species of Harpellales. Mycologia 93: 66-81.

Harper PP, Hynes HBN. 1971. The Capniidae of eastern Canada (Insecta: Plecoptera). Can J Zool 49:921-940.

Lichtwardt RW. 1972. Undescribed genera and species of
Harpellales (Trichomycetes) from the guts of aquatic insects. Mycologia 64:167-197.

, 1986. The Trichomycetes: fungal associates of arthropods. New York: Springer-Verlag. 343 p.

, Cafaro M, White MM. 2001a. The Trichomycetes: Fungal Associates of Arthropods. http:// www.nhm.ku.edu/\%7Efungi/Monograph/Text/ Mono.htm

-, Moss ST. 1981. Vegetative propagation in a new species of Harpellales, Graminella microspora. Trans Brit Mycol Soc 76:311-316.

- - Peterson SW, Williams MC. 1991. Ejectosporus, an unusual new genus of Harpellales in winter-emerging stonefly nymphs (Capniidae) and a new species of Paramoebidium (Amoebidiales). Mycologia 83:389-396.

- White MM, Colbo MH. 2001b. Harpellales in Newfoundland aquatic insect larvae. Mycologia 94:764-773.

Misra JK, Lichtwardt RW. 2000. Illustrated genera of Trichomycetes: fungal symbionts of insects and other arthropods. Enfield, New Hampshire: Science Publishers Inc. $155 \mathrm{p}$.

Peterson SW, Lichtwardt RW. 1983. Capniomyces stellatus and Simuliomyces spica: new taxa of Harpellales (Trichomycetes) from winter-emerging stoneflies. Mycologia 75:242-250.

Stewart KW, Stark BP. 1988. Nymphs of North American stonefly genera (Plecoptera). Denton, Texas: Univ North Texas Press. 460 p.

White MM. 2002. Taxonomic and molecular systematic studies of the Harpellales (Trichomycetes) toward understanding the diversity, evolution and dispersal of gut fungi [Doctoral dissertation]. Lawrence: Univ. Kansas. $172 \mathrm{p}$.

, Lichtwardt RW. 2004. Fungal symbionts (Harpellales) in Norwegian aquatic insect larvae. Mycologia 96: 890-910.

Williams MC, Lichtwardt RW. 1993. A new monotypic fungal genus, Allantomyces, and a new species of Legeriomyces (Trichomycetes, Harpellales) in the hindgut of a Western Australian mayfly nymph (Tasmanocoenis sp.). Can J Bot 71:1109-1113. 